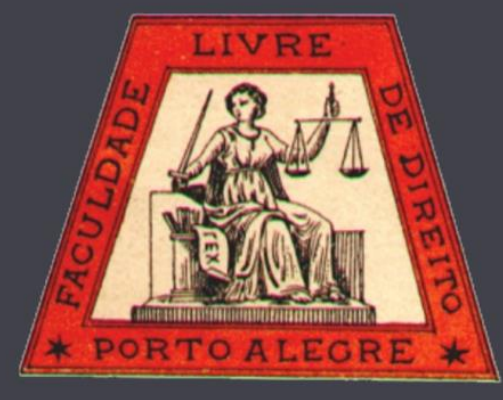

\title{
O controle jurisdicional dos atos políticos: uma força entre a tirania e a judiciocracia
}

The judicial review of political acts: a force between the tyranny and the judiciocracy

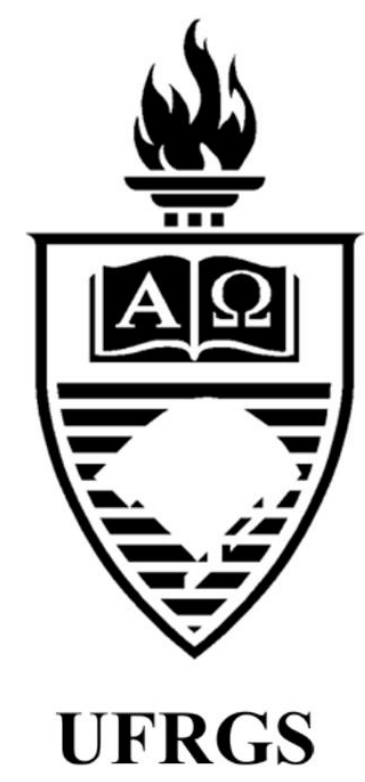

José Everton da Silva Universidade do Vale do Itajaí

Alexandre dos Santos Priess

Universidade do Vale do Itajaí

Guilherme Thomé de Melo

Universidade do Vale do Itajaí 


\title{
O controle jurisdicional dos atos políticos: uma força entre a tirania e a judiciocracia
}

\author{
The Judicial review of political acts: a force between the tiranny and the judiciocracy
}

José Everton da Silva*

Alexandre dos Santos Priess ${ }^{* *}$

Guilherme Thomé de Melo***

\section{REFERÊNCIA}

SILVA, José Everton da; PRIESS, Alexandre dos Santos; MELO, Guilherme Thomé de. O controle jurisdicional dos atos políticos: uma força entre a tirania e a judiciocracia. Revista da Faculdade de Direito da UFRGS, Porto Alegre, n. 35, vol. esp., p. 98-114, dez. 2016.

\section{RESUMO}

O Estado deve operar, mediante seus três ramos, de maneira harmônica e, para este fim, há a atividade de controle estatal, exercida por cada um deles reciprocamente. No entanto, existem hipóteses de controle controversas, tais como a circunstância de a função judiciária fiscalizar os atos políticos emanados pelo Governo. A presente pesquisa visou discutir a viabilidade do exercício do controle jurisdicional de atos políticos com a finalidade de proteger e aplicar os direitos fundamentais que possam ser por eles ameaçados ou violados, a partir da interpretação concretizadora da Constituição. Para tanto, utilizou-se o método indutivo para abordar tópicos referentes às funções política e jurisdicional do Estado e ao dever que este tem de concretizar os direitos fundamentais. $\mathrm{O}$ trabalho resultou na constatação da possibilidade do controle jurisdicional dos atos políticos quando prejudiciais aos direitos fundamentais.

\section{PALAVRAS-CHAVE}

Ato político. Controle jurisdicional. Direitos Political act. Judicial review. Fundamental rights.

\begin{abstract}
The State must operate, by its three branches, harmoniously and, for this purpose, there is the checks and balances system mutually exercised by each one. However, there are controversial hypotheses of review, such as the judicial review of political acts issued by the Government. This research aimed to discuss the feasibility of the judicial review of political acts with the intention of protecting and enforcing fundamental rights that may be threatened or violated by them, through the concretist interpretation of the Constitution. To achieve this objective, it was used the inductive method to address topics relating to the political and judicial functions of the State and its obligation in fulfilling the fundamental rights. The analysis resulted in the finding of the possibility of judicial review of political acts when harmful to fundamental rights.
\end{abstract}

\section{KEYWORDS}

fundamentais.

\section{SUMÁRIO}

Introdução. 1.Teoria da separação as funções do Estado. 2. Função política do Estado. 3. Ato político. 4. Controle como atividade estatal em sentido amplo. 5. Princípio da inafastabilidade do controle jurisdicional. 6. Problemáticas da judicialização da política e da politização da justiça. 7. Concretização dos direitos fundamentais. 8. O exercício da jurisdição constitucional perante a política. Conclusão. Referências.

\footnotetext{
* Professor titular da Universidade do Vale do Itajaí - UNIVALI. Possui graduação em Direito pela Universidade Federal de Santa Maria (1992), graduação em Ciências pela Universidade Federal de Santa Maria (1984) e Mestrado em Desenvolvimento Regional pela Fundação Universidade Regional de Blumenau (2002) e Doutorado em Ciência Jurídica pela Universidade do Vale do Itajaí (2016).

*** Professor da Universidade do Vale do Itajaí - UNIVALI. Mestrando em Ciência Jurídica no Programa de PósGraduação Stricto Sensu da Universidade do Vale do Itajaí - UNIVALI.

*** Graduando em Direito na Universidade do Vale do Itajaí - UNIVALI.
} 


\section{INTRODUÇÃO}

Nos últimos tempos, o Supremo Tribunal Federal tem sido palco de discussão sobre assuntos sensíveis concernentes ao Governo. A razão disto é evidente, pois a necessidade de uma resposta definitiva para tais debates tende a leválos ao âmbito judicial; e o Supremo Tribunal Federal, como guardião da norma constitucional, inevitavelmente envolve-se na questão. A ocorrência de tais intervenções judiciais, cada vez mais frequentes, resulta na preocupação em relação ao equilíbrio das funções estatais, à delimitação da jurisdição constitucional e à possibilidade de que de fato haja assuntos que escapam à esfera judicial quando a matéria apreciada é essencialmente política, como no caso dos atos políticos.

O objetivo deste estudo é investigar a partir da perspectiva doutrinária, jurisprudencial e da norma constitucional se o controle jurisdicional pode alcançar os atos políticos com a finalidade de impedir que o Governo os pratique de modo arbitrário ou se esta ingerência culminaria na extrapolação da jurisdição, pelo que a função judiciária avocaria atribuições governamentais de competência das funções executiva e legislativa, o que afrontaria o princípio da separação das funções do Estado.

Para tanto, o presente artigo tem seu início ao tratar da distribuição funcional do Estado e de seu sistema de freios e contrapesos. Em seguida, aborda-se o conceito, as características e a titularidade do ato político.

Após isso, discute-se acerca do controle em sentido amplo, como atividade exercida pelo Estado relacionada ao sistema de freios $\mathrm{e}$ contrapesos, com a apresentação de conceito, sua justificativa e suas classificações.

Por fim, ingressa-se no cerne da discussão ao explorar a viabilidade do exercício do controle jurisdicional dos atos políticos a partir do princípio da inafastabilidade do controle jurisdicional e sua relação com o princípio da separação das funções estatais. Além disto, a abrangência da jurisdição constitucional é debatida com base nas problemáticas que envolvem a judicialização da política e a politização da justiça, discorrendo-se também a respeito da necessidade da aplicação da máxima da proporcionalidade e da concretização dos direitos fundamentais ao se deparar com atos políticos que conflitem com tais direitos.

$\mathrm{Na}$ conclusão deste trabalho, são apresentados pontos finais destacados, seguidos da estimulação à continuidade dos estudos e das reflexões sobre os limites tanto dos atos políticos e como de seu controle jurisdicional.

A presente pesquisa parte dos seguintes problemas formulados: a) Pode o Poder Judiciário interferir nas decisões do Governo? b) É a discricionariedade do ato político absoluta? c) Onde se encontram os limites da Jurisdição Constitucional em relação aos atos políticos?

Para responder tais problemas, foram levantadas as seguintes hipóteses: a) O controle jurisdicional dos atos políticos é inviável por ferir o princípio da separação das funções do Estado. b) É sempre necessário o controle jurisdicional dos atos políticos para garantir o equilíbrio e a harmonia dos Poderes, pois nenhuma função ou ato estatal pode contrariar os dispositivos constitucionais, nem ser imune à apreciação judicial. c) É possível o controle jurisdicional dos atos políticos em determinados casos, enquanto em outros constata-se sua impossibilidade, devido ao teor exclusivamente político da matéria envolvida.

Quanto à Metodologia empregada, registra-se que, na Fase de Investigação, "momento no qual o Pesquisador busca e recolhe os dados, sob a moldura do Referente estabelecido" (PASOLD, 2008, p. 83), foi utilizado o Método Indutivo, consistente em "pesquisar e identificar as partes de um 
fenômeno e colecioná-las de modo a ter uma percepção ou conclusão geral" (PASOLD, 2008, p. 86). Na fase de tratamento de dados, utilizouse o Método Cartesiano - cujas quatro regras são evidência, dividir, ordenar e avaliar (LEITE, 2001, p. 22-26) -, e o Relatório dos Resultados expresso no presente estudo é composto por base da lógica indutiva.

\section{TEORIA DA SEPARAÇÃO DAS FUNÇÕES DO ESTADO}

O primeiro registro do reconhecimento das funções essenciais a um Governo ideal pode ser encontrado na antiguidade a partir das convicções de Aristóteles (2007, p. 170), segundo as quais a Cidade-Estado seria regida por três elementos diversos: as assembleias deliberativas, as magistraturas e a parte judiciária.

A organização do Estado com Poderes bem definidos, todavia, somente se iniciou com John Locke, para o qual, como explica Norberto Bobbio (1997, p. 231), existem dois Poderes oriundos do poder civil: o Legislativo e o Executivo.

Mais tarde, com base nos ideais de tais pensadores, Montesquieu (2005, p. 202) consagra a teoria da separação dos Poderes, a fim de evitar a concentração de Poderes em uma mesma pessoa ou assembleia, o que segundo ele resultaria no constante risco de o detentor de poderes acumulados atuar arbitrariamente. De acordo com ele, quem detivesse tanto o Poder Legislativo como o Poder Executivo poderia legislar de forma despótica e executar suas próprias leis para atingir seus desígnios pessoais. Assim, Montesquieu consolida a divisão do Estado em três funções diversas: "Há, em cada Estado, três espécies de poderes: o poder legislativo, o poder executivo das coisas que dependem do direito das gentes, e o executivo das que dependem do direito civil."
(MONTESQUIEU, 2005, p. 201).

Em relação a isso, elucida Paulo Bonavides (2005, p. 139) que o "poder executivo das coisas que dependem do direito civil" ao qual Montesquieu se refere corresponde ao Poder Judiciário. Conforme o autor, sob a ótica de Montesquieu o Poder Legislativo tem a função primária de elaborar, alterar e revogar de leis; o Poder Executivo deve tratar de paz, guerra e diplomacia, garantir a segurança e prevenir invasões; e o Poder Judiciário pune crimes e resolve litígios civis.

Hans Kelsen identifica ainda uma função legislativa negativa do Estado, pois, como assevera Luis Roberto Barroso, o controle de constitucionalidade exercido pelo Tribunal Constitucional não tem natureza judicial, mas legislativa negativa, visto que o detentor de tal prerrogativa é capaz de desconstituir a lei incompatível com a norma constitucional: "Na perspectiva dos juristas e legisladores europeus, o juízo de constitucionalidade acerca de uma lei não tinha natureza de função judicial, operando o juiz constitucional como legislador negativo, por ter o poder de retirar uma norma do sistema" (2012, p. 39).

Esses Poderes, conforme ensina José Afonso da Silva, são desdobramentos do poder político que cabe ao Estado e que, segundo ele, é uno, indivisível e indelegável (2005, p. 107). O autor define o poder político como "uma energia capaz de coordenar e impor decisões visando à realização de determinados fins." (2005, p. 106). Trata-se, portanto, do poder regente da sociedade, que surge com o Estado e origina os demais Poderes da clássica tripartição e todas as suas forças derivativas, que apesar de separadas formam uma unidade que almeja satisfazer o interesse comum da sociedade.

Ligado à concepção da teoria da separação dos Poderes está o sistema de freios e contrapesos também preconizado por Montesquieu, como demonstra Paulo Bonavides 
(2005, p. 141), que o considera um instrumento que tem por objetivo alcançar o equilíbrio entre os Poderes com sua interferência recíproca.

James Madison (2001, p. 250) desvenda que a intenção de Montesquieu não era a de que as competências fundamentais do Estado fossem totalmente separadas sem que houvesse controle de umas sobre as outras quanto aos atos que praticam, seu desígnio com tal distinção era apenas evitar que um mesmo detentor de uma competência exercesse uma outra. Deste modo, o mesmo autor (2001, p.251) arremata: “(...) there is not a single instance in which the several departments of power have been kept absolutely separate and distinct."1

Sobre esse tema, Paulo Bonavides (2007, p. 73) considera os Poderes como aspectos diversos da soberania que se manifestam em diferentes ângulos, portanto avalia como erradas as ideias de separação e divisão, logo propõe sua substituição por expressões como distinção, coordenação e colaboração. Além disto, segundo ele, há ainda uma predileção pela utilização do termo funções em vez de Poderes, o que aponta para a integração entre eles de modo a se compatibilizar com a ampla abrangência da ação do Estado.

Nesse entendimento, Georg Jellinek conclui que o "poder não se divide subjetivamente, nem mesmo como atividade; o que se divide é o objeto do poder, ao qual se dirige a atividade estatal" (JELLINEK apud BONAVIDES, 2007, p. 78).

Atualmente, embora haja ainda a denominação de Poderes, a distribuição de tais funções e o sistema de freios e contrapesos a ela relativos podem ser encontrados na Constituição da República Federativa do Brasil de $1988^{2}$, que prevê em seu art. 20: "São Poderes da União,

\footnotetext{
${ }^{1}$ Tradução livre dos autores: "Não há nenhum caso em que os diversos departamentos do poder tenham se separado e distinguido de forma absoluta".

${ }^{2}$ De agora em diante tratada como CRFB/88.
}

independentes e harmônicos entre si, o Legislativo, o Executivo e o Judiciário."

José Afonso da Silva esclarece que a independência dos Poderes é a qualidade que possibilita seu exercício sem a necessidade de sujeição à vontade dos demais Poderes e sua auto-organização interna. A harmonia entre os Poderes, ao seu turno, conforme este autor, é a relação mútua no exercício de atribuições comuns a todos eles e a mitigação de suas independências com o propósito de permitir o seu controle recíproco, o que estabelece o sistema de freios e contrapesos, a fim de buscar o adequado exercício das funções estatais (SILVA, 2005, p.110).

A distinção das funções, portanto, visa não somente tornar mais eficiente a atividade estatal, mas também rechaçar qualquer eventual tirania de seus detentores ao impedir sua concentração e utilizar o sistema de freios e contrapesos que permite intervenções mútuas entre as competências fundamentais do Estado, com vistas à harmonia necessária ao seu desempenho ideal.

\section{FUNÇÃO POLÍTICA DO ESTADO}

A função política, segundo Maria Sylvia Zanella di Pietro, é aquela realizada pelos Poderes Executivo e Legislativo, com a predominância do primeiro, eis que o sistema governamental presente no Brasil é o presidencialista, o que confere ao Chefe do Executivo uma vasta gama de competências, embora habitualmente suas iniciativas de caráter político se sujeitem à aprovação pelo Legislativo, que assim também participa de tais decisões políticas (2014, p. 54).

Para Celso Antônio Bandeira de Mello, a função política é estranha às clássicas funções executiva, legislativa e jurisdicional do Estado, por não se encaixam em nenhuma delas, e pode ser definida como aquela que envolve os "atos de 
superior gestão da vida estatal ou de enfrentamento de contingências extremas que pressupõem, acima de tudo, decisões eminentemente políticas" (2010, p. 36-37).

A função política é, então, atribuição do Governo, o qual, conforme explica Hely Lopes Meirelles, conceitua-se em sentido formal como o "conjunto de Poderes e órgãos constitucionais", em sentido material como "o complexo de funções estatais básicas" e em sentido operacional como "a condução política dos negócios públicos”. Hely ainda elucida que incumbe ao Governo além da condução dos negócios públicos, o comando do Estado e a fixação de seus objetivos e de sua ordem jurídica, tarefas que realiza por meio da soberania ou autonomia política (2010, p. 65).

A partir de uma perspectiva geral, José Afonso da Silva define Governo como o "conjunto de órgãos mediante os quais a vontade do Estado é formulada, expressada e realizada, ou o conjunto de órgãos supremos a quem se incumbe o exercício das funções do poder político" (2005, p. 108).

Observa-se, dessa forma, que a função política cabe ao Governo e, apesar de ser exercida pelas funções executiva e legislativa, consiste em atividade estranha a todas as funções do Estado. Isto porque ela deriva diretamente do poder político do Estado, motivo pelo qual envolve decisões igualmente políticas para a direção estatal, com o objetivo de que o Poder Público corresponda à expectativa da sociedade $\mathrm{e}$ às situações eventuais que escapam à atividade cotidiana da Administração Pública.

\section{ATO POLÍTICO}

O ato político é de difícil conceituação, haja vista que sua natureza política lhe confere ampla abrangência, o que resulta na diversidade de definições encontradas na doutrina.

Diógenes Gasparini (2003, p. 121) classifica os atos políticos como atos administrativos em face do ordenamento jurídico pátrio e por isto devem observar seu regime jurídico.

Celso Antônio Bandeira de Mello (2010, p. 384) diverge de tal entendimento e assevera que os atos políticos diferem dos atos administrativos, nem mesmo se relacionam à função administrativa: "Por corresponderem ao exercício de função política e não administrativa, não há interesse em qualificá-los como atos administrativos, já que sua disciplina é peculiar."

Além disso, Celso Antônio Bandeira de Mello considera que os atos políticos apresentam natureza singular e são exercidos pelo Estado em sua função puramente política, pelo que ostentam elevada margem de discricionariedade e se vinculam diretamente às disposições constitucionais, razão pela qual são imediatamente infraconstitucionais, em oposição aos atos administrativos, que são infralegais e, portanto, se vinculam tanto à lei como à norma constitucional. Ele ainda cita como exemplos de atos políticos: o indulto, a iniciativa de lei pelo Executivo e sua sanção ou veto.

Similar é a compreensão de José dos Santos Carvalho Filho a respeito dos atos políticos, para o qual eles não são propriamente administrativos, mas tipicamente de governo, praticados no exercício da competência constitucional da cúpula diretiva do país e têm por fim a condução de políticas, diretrizes e estratégias do Governo (CARVALHO FILHO, 2015, p. 1057).

Hely Lopes Meirelles (2010, p. 46), ao seu turno, sustenta que o ato político jamais pode ser analisado de maneira independente, porquanto "é sempre ato administrativo, ato legislativo ou ato judiciário informado de fundamento político." Para o autor, o ato político é um ato de governo exercido com discricionariedade pelo detentor de qualquer dos Poderes do Estado, motivo pelo qual pode ser 
praticado até mesmo pelo Poder Judiciário, como nos casos em que este formula proposta de criação de tribunais inferiores e indica advogado ou membro do Ministério Público para compor o quinto constitucional (MEIRELLES, 2010, p. 748).

Essa concepção de ato político se relaciona com a definição de poder político e com a noção de distribuição de competências estatais, visto que poder político, como função primordial do Estado, também não pode ser considerado de forma isolada, dado seu desdobramento nas funções executiva, legislativa e judiciária.

Em busca de um conceito genérico de ato político, Oreste Renelletti sugere: "é aquele que promana do Governo, no exercício do poder político" (1945, p. 37).

Marques Oliveira, por sua vez, propõe uma diferenciação entre ato político e ato de governo. Para este autor, ato político é aquele que apresenta discricionariedade absoluta e que é praticado por agente político, no exercício de competência exclusiva, especificada na legislação constitucional ou em leis complementares a esta, para a condução dos negócios públicos e a satisfação do bem comum (OLIVEIRA, 1988, p. 16).

Já o ato de governo, segundo Marques Oliveira, envolve o exercício da função administrativa pelo agente político:

\section{[...] é praticado com discricionariedade relativa, por agente político no exercício de atribuições administrativas expressas em lei ou nesta implícitas, para execução eficiente das tarefas do setor público a seu cargo, com vistas também ao bem público. (1983, p. 16)}

Apesar da multiplicidade de definições, este estudo empregará o termo ato político como aquele que é imediatamente infraconstitucional, revestido de alto grau de discricionariedade e realizado por agentes políticos no desempenho do poder político para a condução dos negócios públicos.

\section{CONTROLE COMO ATIVIDADE}

\section{ESTATAL EM SENTIDO AMPLO}

Marques Oliveira (1983, p. 67) leciona que a atividade de controle advém dos Poderes do Estado e lhes permite discutir os atos de uns dos outros, ainda que apresentem presunção de legalidade.

Para Hely Lopes Meirelles (2010, p. 697), o Controle é "a faculdade de vigilância, orientação e correção que um Poder, órgão ou autoridade exerce sobre a conduta funcional de outro". Ademais, trata-se, segundo aquele autor de uma faculdade onímoda, ou seja, que possui cobertura absoluta, já que alcança a todos os Poderes do Estado e pode ser exercido igualmente por todos eles (2010, p. 698).

O Controle é compreendido por Marques Oliveira (1983, p. 61) como uma função estatal autônoma, tão importante quanto às tradicionais funções judicativa, normativa e administrativa.

Infere-se, assim, que o Controle é uma atribuição do Estado que se realiza entre suas funções ou em si próprias, referente à fiscalização de seus atos, com base na qual formula uma orientação relativa a um comportamento a ser seguido ou a uma correção de erros ou desvios de finalidade, legal ou constitucional, a ser buscada.

A necessidade de se existir a atividade de controle estatal se origina da possibilidade de haver arbitrariedade pelos detentores do poder no desempenho de suas funções. Em razão disto, Montesquieu, que consagrou o sistema de freios e contrapesos, defende que somente há liberdade política se o abuso de poder for contido e propõe que, para este fim, é preciso que exista o Controle, o qual deve ser exercido pelos próprios Poderes, ou funções estatais: "Para que não se possa abusar do poder, é preciso que, pela disposição das coisas, o poder limite o poder" 
(MONTESQUIEU, 2005, p. 200).

Como é possível se verificar, o Controle consiste no conjunto de atribuições necessárias à realização do sistema de freios e contrapesos e visa conceder às funções do Estado meios para que realizem a fiscalização recíproca de suas atividades, a fim de assegurar que sejam desempenhadas de maneira adequada.

Outrossim, Marques Oliveira (1983, p. 13) ressalta que há o risco de que até mesmo as próprias leis por vezes não alcancem as suas finalidades, as quais são a justiça, a ordem pública e o bem-comum. Segundo este autor o Controle visa garantir que estes fins sejam atingidos, pelo que é uma função de cunho finalístico.

Desse modo, a justificativa de a atividade de controle existir é a ameaça de arbitrariedade ou de contrariedade às normas legais ou constitucionais na atividade de qualquer das funções do Estado.

Em relação à forma, José Afonso da Silva classifica o Controle, segundo a natureza dos organismos controladores, em controle administrativo, "exercido por administradores"; controle jurisdicional, "exercido por órgãos do Poder Judiciário" e controle político "exercido pelo parlamento e seus prepostos e auxiliares" (2005, p. 750).

Posto isso, a seguir se discorrerá acerca do controle jurisdicional, por integrar o tema central da discussão proposta.

\section{PRINCÍPIO DA INAFASTABILIDADE DO CONTROLE JURISDICIONAL}

Segundo José Afonso da Silva (2005, p. 430), o princípio da inafastabilidade do controle jurisdicional, ou princípio da proteção judiciária, é preceito essencial para garantir a eficácia dos direitos subjetivos.

Hely Lopes Meirelles (2010, p. 744) demonstra que o princípio da inafastabilidade do controle jurisdicional integra o sistema de jurisdição judicial única, o qual é adotado no Brasil e está previsto no art. $5^{\circ}, \mathrm{XXXV}$ da CRFB/88: "a lei não excluirá da apreciação do Poder Judiciário qualquer lesão ou ameaça a direito", seja individual ou coletivo, como acrescenta o autor.

José Afonso da Silva (2005, p. 431) destaca a abrangência desse dispositivo constitucional, porquanto também envolve a ameaça a direito, o que "possibilita o ingresso em juízo para assegurar direitos simplesmente ameaçados (...) amplia o direito de acesso ao Judiciário, antes de concretização da lesão." Ainda conforme o autor, há duas garantias decorrentes da redação do art. $5^{\circ}$, XXXV da CRFB/88: "a de que cabe ao Poder Judiciário o monopólio da jurisdição" e o "direito de invocar a atividade jurisdicional sempre que se tenha como lesado ou simplesmente ameaçado um direito, individual ou não, pois a Constituição já não o mais qualifica de individual", razão pela qual do mesmo modo alcança os direitos coletivos (2005, p. 431).

Para José Joaquim Gomes Canotilho, a essência do princípio da inafastabilidade do controle jurisdicional é "a garantia dos direitos fundamentais só pode ser efectiva quando, no caso da violação destes, houver uma instância independente que restabeleça a sua integridade" (2003, p. 274).

De acordo com Celso Ribeiro Bastos (1989, p. 169-170), esse princípio consiste na função jurisdicional, à qual compete a aplicação do ordenamento jurídico quando houver resistência ao seu cumprimento. É a substituição da faculdade do exercício de autotutela pelo particular, ou mesmo por pessoa jurídica de direito público, pela tutela do Poder Judiciário, que, ao conhecer da controvérsia, sobrepõe-se à vontade das partes para dirimir a questão.

Dessa forma, conclui-se que o princípio 
da inafastabilidade do controle jurisdicional possibilita e justifica a atividade jurisdicional do Estado, que a desempenha por meio de sua função judiciária, a qual busca garantir os direitos individuais e coletivos, ao restaurá-los caso violados ou protegê-los se ameaçados.

\section{PROBLEMÁtiCAS DA \\ JUDICIALIZAÇÃO DA POLÍTICA E DA POLITIZAÇÃO DA JUSTIÇA}

Consoante a lição de Karl Loewenstein (1976, p. 321-322), o Tribunal Constitucional, que no Brasil é o Supremo Tribunal Federal, por vezes aprecia conflitos de natureza política, situações em que suas decisões apresentam caráter político, mesmo que manifestadas de forma judicial. Este cenário, para o autor, permite a ampliação da jurisdição constitucional de modo que alcance as questões políticas e os atos de governo, conjuntura tal que é denominada de "judicialização da política", com grande possibilidade de culminar no fenômeno da "politização da justiça":

Dado, sin embargo, que la sustancia del conflito es de naturaleza política, la función del Tribunal Constitucional adquiere necessariamente um carácter político aunque la decisión esté revestida de forma judicial. La competencia del tribunal se extiende así a materias que em otros lugares están consideradas como "cuestiones políticas" y como actes de gouvernment no justiciables. Esta situación es designada diferentemente como la "judicialización de la política" que, así será alegado, conduce casi inevitablemente a la "politización de la justicia". 3

\footnotetext{
${ }^{3}$ Tradução livre dos autores: "Dado, no entanto, que o cerne do conflito é de natureza política, a função do Tribunal Constitucional adquire necessariamente um caráter político ainda que a decisão esteja revestida de forma judicial. A competência do tribunal se estende assim a matérias que em outros lugares são consideradas como 'questões políticas' e como atos de governo não suscetíveis da apreciação da justiça. Esta situação é
}

Torbjörn Vallinder (1995, p. 13) conceitua "judicialização da política" como a expansão da jurisdição sobre os âmbitos políticos que pode acontecer de duas formas: com a transferência da competência governamental de emitir decisões políticas à função judiciária ou pela aplicação habitual de métodos decisórios que extrapolam a alçada judicial:

\begin{abstract}
Thus the judicialization of politics should normally mean either (1) the expansion of the province of the courts or the judges at the expense of the politicians and/or the administrators, that is, the transfer of decision making rights from the legislature, the cabinet, or the civil service to the courts or, at least, (2) the spread of judicial decision-making methods outside the judicial province proper. $^{4}$
\end{abstract}

A politização da justiça, por seu turno, de acordo com Marcelo Neves, é a circunstância na qual "as cortes constitucionais estejam decidindo, fundamentalmente, de acordo com critérios políticos" (NEVES, 2006, p. 235).

A importância de se separar Direito e Política é demonstrada por Eduardo Appio (2008, p. 157), que sustenta que é vedada ao Poder Judiciário a revisão do conteúdo das decisões políticas, porquanto isto configuraria uma afronta à representatividade encontrada no regime democrático:

[...] a margem de discricionariedade política outorgada pelo próprio constituinte aos governos eleitos não pode ser suprimida por força de uma

designada diferentemente como a 'judicialização da política' que, como será demonstrada, conduz quase inevitavelmente à "politização da justiça"'.

${ }^{4}$ Tradução livre dos autores: Assim, a judicialização da política deveria normalmente significar (1) a expansão da jurisdição dos tribunais e juízes em detrimento de políticos e/ou administradores, ou seja, a transferência da competência para a tomada de decisões do legislador, gabinete ou serviço civil aos tribunais ou, no mínimo (2) a propagação de métodos de tomadas de decisão judiciais fora da jurisdição adequada. 
decisão judicial, sob pena de afronta ao sistema representativo e indevida invasão de atribuições políticas. (APPIO, 2008, p. 159)

Eduardo Appio (2008, p. 158), no entanto, entende que é cabível a ingerência jurisdicional quando legitimada pelo próprio sistema representativo, nas situações em que "o governo eleito se distanciar dos programas inicialmente propostos".

Para Ronald Dworkin (2005b, p. 3-6), por sua vez, as decisões judiciais devem ser sempre políticas em algum sentido, contanto que sejam fundamentadas em argumentos de princípio político, os quais "recorrem aos direitos políticos de cidadãos individuais", enquanto não devem ser alicerçadas em argumentos de procedimento político, que são aqueles que "exigem que uma decisão particular promova alguma concepção do bem-estar geral ou do interesse público".

Ronald Dworkin, assim, afirma que as decisões políticas podem versar sobre duas classes de questões políticas: aquelas sensíveis à eleição e as que são insensíveis à eleição. Segundo ele, sensíveis à eleição são as questões de política, "aquelas cuja solução correta, por questão de justiça, depende essencialmente do caráter e distribuição das preferências dentro da comunidade política", tais como a decisão de usar recursos públicos para construir um novo centro esportivo ou sistema de rodoviário. As questões de princípio, por sua vez, como alega o autor, são insensíveis à eleição, o que é o caso da decisão de aplicar a pena de morte, pois há cenários que são injustos e contrariam princípios basilares do Estado contemporâneo, pelo que ainda que a maioria dos membros de uma comunidade se manifeste a favor deles, não lhes retira tais características (DWORKIN, 2005a, p. 281-282).

Logo, Ronald Dworkin sustenta que as decisões que envolvem questões insensíveis a eleição são passíveis de controle judicial, enquanto aquelas que tratem de questões sensíveis a eleição, não podem ser apreciadas pelo Judiciário.

\section{CONCRETIZAÇÃO DOS DIREITOS FUNDAMENTAIS}

Karl Loewenstein (1976, p. 390) ensina que os direitos fundamentais são o maior limite que existe ao exercício do poder estatal, pois não podem ser violados nem mesmo pelo eleitorado, eis que inalienáveis, o que certamente também impede que os representantes eleitos por este os infrinjam:

\begin{abstract}
Entre todos los límites impuestos al poder del Estado se considera que el más eficaz es el reconocimiento jurídico de determinados âmbitos de autodeterminación individual em los que el Leviatán no puede penetrar. El acceso a estas zonas prohibidas está cerrado a todos los detentadores del poder, al gobierno, al parlamento y, dado que los derechos fundamentales son "inalienables", también al electorado. ${ }^{5}$
\end{abstract}

De acordo com José Afonso da Silva (2005, p. 181), os direitos fundamentais são inalienáveis, imprescritíveis, irrenunciáveis e históricos. Segundo o autor, eles podem ser denominados das mais diferentes formas, tais como: "direitos naturais, direitos humanos, direitos do homem, direitos individuais, direitos públicos subjetivos, liberdades fundamentais, liberdades públicas e direitos fundamentais do homem" (SILVA, 2005, p. 175).

Norberto Bobbio destaca esse caráter histórico dos direitos fundamentais, o autor

\footnotetext{
${ }^{5}$ Tradução livre dos autores: "Entre todos os limites impostos ao poder do Estado se considera que o mais eficaz é o reconhecimento jurídico de determinados âmbitos de autodeterminação individual nos quais o Leviatã não pode ingressar. O acesso a estas zonas proibidas está defeso a todos os detentores do poder, ao Governo, ao parlamento e, dado que os direitos fundamentais são 'inalienáveis', também ao eleitorado".
} 
explica que eles são "nascidos em certas circunstâncias, caracterizadas por lutas em defesa de novas liberdades contra velhos poderes, e nascidos de modo gradual, não todos de uma vez e nem de uma vez por todas" (BOBBIO, 2004, p. 25).

Ingo Wolfgang Sarlet (2004, p. 35-36) sustenta que "direitos fundamentais" e "direitos humanos", apesar de habitualmente serem tratados como sinônimos, é possível diferenciálos. O autor ensina que direitos fundamentais são "direitos do ser humano reconhecidos e positivados na esfera do direito constitucional positivo de determinado Estado", ao passo que os direitos humanos se revestem de validade universal e caráter supranacional, haja vista que são referentes aos "documentos de direito internacional, por referir-se àquelas posições jurídicas que se reconhecem ao ser humano como tal, independentemente de sua vinculação com determinada ordem constitucional".

Acerca dos direitos fundamentais, Konrad Hesse (2009, p. 81) defende que sua principal finalidade é de conferir ao indivíduo a garantia de que o Poder Público não viole a sua esfera de liberdade, pois, caso ele seja ofendido em qualquer direito fundamental, pode procurar a proteção jurisdicional para evitar que tal lesão prospere (2009, p. 136).

Ingo Wolfgang Sarlet (2004, p. 351-353) elucida que as normas de direitos fundamentais têm aplicabilidade imediata, conforme o art. $5^{\circ}$, § $1^{\circ}$ da CRFB/88, dispositivo ao qual o Poder Público está vinculado quanto à sua atividade, que ainda deve buscar aplicar os direitos fundamentais com a maior eficácia possível. Por este motivo, as funções do Estado somente podem afetar os direitos fundamentais quando houver a devida justificativa, de outro modo devem sempre buscar a realização deles.

Os direitos fundamentais podem assim ser aplicados através da concretização (Konkretisierung), como orienta Konrad Hesse
(2009, p. 206), segundo o qual se trata da interpretação constitucional de índole criativa permitida, desde que observe norma, praticada com a intenção de extrair o conteúdo implícito dos dispositivos constitucionais para aproveitá-lo ao caso concreto.

Paulo Bonavides (2004, p. 604) ensina que a concretização é uma técnica de interpretação que persegue a vontade do legislador ou da lei mediante a compreensão do conteúdo da norma a ser aplicada e se distingue dos métodos interpretativos tradicionais (gramatical, lógico, histórico, sistemático e teleológico), os quais não são adequados para a assimilação do alcance normativo pluridimensional dos direitos fundamentais ou do sentido das cláusulas introdutivas e gerais. $\mathrm{O}$ autor se filia ao entendimento de Konrad Hesse no tocante à dúvida ser elemento indispensável do processo interpretativo, sem a qual "não se interpreta, e raramente se faz mister também alguma interpretação" (BONAVIDES, 2004, p. 605).

A observância dos direitos fundamentais repercute também sobre os atos políticos como advoga Hely Lopes Meirelles (2010, p. 747), o qual explica que a discricionariedade política restringe o controle judicial, porém não o impede de ocorrer, pois o Poder Judiciário pode intervir neles quando forem lesivos aos direitos individuais ou ao patrimônio público.

Nesse raciocínio, Rui Barbosa (1983, p. 144), o qual prega que os atos políticos ostentam acentuada imunidade em relação ao controle jurisdicional, admite a hipótese de este suceder nos casos em que violem direitos constitucionais do indivíduo.

Similar é o entendimento de Paulo Bonavides (2004, p. 324), que afirma que os atos legislativos e governamentais "fogem à alçada judicial, não sendo objeto de exame de constitucionalidade, salvo se interferirem com a existência constitucional de direitos individuais." 
José dos Santos Carvalho Filho (2015, p. 1058) elucida que há atualmente consenso doutrinário quanto à possibilidade do controle jurisdicional dos atos políticos que violem direitos não somente individuais, mas também coletivos.

Para assegurar a concretização dos direitos fundamentais, Robert Alexy (2008, p. 120) assevera que em relação a eles pode ser aplicada a máxima ou exame da proporcionalidade quando apresentarem caráter principiológico.

De acordo com Humberto Ávila, o "exame de proporcionalidade aplica-se sempre que houver uma medida concreta destinada a realizar uma finalidade" (2005, p. 113-114).

Segundo Humberto Ávila, cabe o exame de proporcionalidade sobre qualquer ato estatal, que somente terá validade se atender a três requisitos. $\mathrm{O}$ primeiro é o exame de adequação, conforme o qual "o meio deve contribuir para a promoção do fim, pois se sua utilização só é justificada pelo fim, não sendo ele promovido, o uso do meio acaba não mais possuindo justificativa." O segundo é o exame de necessidade, para o qual "o meio deve ser o mais suave dentre os meios disponíveis, pois o Estado não apenas tem a obrigação de atingir seus fins próprios, mas, também, tem a obrigação de proteger ao máximo os direitos dos particulares, e isso somente é possível se ele adotar o meio menos restritivo". O último é o exame de proporcionalidade em sentido estrito, que determina que "o meio deve proporcionar vantagens superiores às desvantagens, pois $\mathrm{o}$ Estado, tendo obrigação de realizar todos os princípios constitucionais, não pode adotar um meio que termine por restringi-los mais do que promovê-los em seu conjunto" (ÁVILA, 2004, p. 373).

Deve-se destacar que o exame de adequação é a verificação finalística do ato, portanto é equivalente à análise de desvio de finalidade. O Supremo Tribunal Federal recentemente aplicou este exame finalístico em assunto de repercussão nacional que foi o caso da nomeação de Luiz Inácio Lula da Silva à Ministro de Estado. O Ministro Gilmar Mendes, relator da decisão, fundamentou na tese de desvio de finalidade para suspender a eficácia da ato de nomeação ${ }^{6}$ :

\begin{abstract}
Não importam os motivos subjetivos de quem pratica o ato ilícito. O vício, o ilícito, tem natureza objetiva. A bem dizer, a comprovação dos motivos subjetivos que impeliram a mandatária à prática, no caso em tela, configura elemento a mais a indicar a presença do vício em questão, isto é, do desvio de finalidade. (...)

(...) Nesse contexto, o argumento do desvio de finalidade é perfeitamente aplicável para demonstrar a nulidade da nomeação de pessoa criminalmente implicada, quando prepondera a finalidade de conferir-lhe foro privilegiado. (BRASIL, 2016, p. 19-20)
\end{abstract}

Constata-se, assim, que o controle jurisdicional dos atos políticos é viável quando estes violarem os direitos fundamentais, os quais devem ser protegidos e aplicados por meio da concretização oriunda da interpretação norma constitucional e do exame de proporcionalidade a eles relativo.

\section{O EXERCÍCIO DA JURISDIÇÃO CONSTITUCIONAL PERANTE A POLÍTICA}

É nítida a necessidade de se encontrar um ponto de equilíbrio na atuação do Judiciário quando exerce seu controle sobre os atos políticos, visto que a intervenção excessiva pode prejudicar a harmonia entre as funções do Estado pretendida pela norma constitucional. ${ }^{6}$ Embora nesta decisão tenha sido denominada de ato
administrativo, a nomeação de Ministro de Estado é ato
político conforme a doutrina majoritária. 
Sobre este perigo, Karl Loewenstein (1976, p. 325) explica que a judicialização da política é proporcionada pela posição absoluta na qual se encontra a Corte Constitucional dentro do processo do poder e isto pode resultar no que ele chama de "judiciocracia", que seria a situação em que o Governo se encontra sob a supremacia dos juízes:

Instalar um tribunal como árbitro supremo del proceso del poder - y éste es el núcleo de la "judicialización de la política" - , transformaria, en último término, el sistema gubernamental em um domínio de los jueces o em una "judiciocracia". 7

Eduardo Appio alerta que tal "judiciocracia" seria danosa sob a perspectiva democrática, haja vista que os juízes não são eleitos pelo povo para cumprirem as funções executiva e legislativa, nem são detentores de mandatos com tempo fixo de exercício:

Um governo de juízes seria de todo lamentável, não pelo simples fato de que não tenham sido eleitos para gerirem a máquina administrativa ou para inovarem no ordenamento jurídico, mas pela simples razão de que não detêm mandato fixo. (APPIO, 2008, p. 70)

Nota-se que em um eventual governo de juízes, como agentes públicos que gozam de vitaliciedade em seus cargos, não haveria garantia alguma de que a vontade popular fosse efetuada por eles em vez de aplicarem suas próprias convicções políticas.

Acerca disso, Jürgen Habermas defende que os discursos jurídicos, cuja especialidade é direcionada à aplicação de normas, não estão aptos a substituir os discursos políticos, os quais fundamentam as normas e determinam os objetivos, tarefas estas que exigem "a inclusão de todos os atingidos" (2003, p. 329-330).

A fim de não violar o princípio democrático, é preciso, portanto, estabelecer os limites do controle jurisdicional dos atos políticos, visto que não resta dúvida que este deve ser exercido para concretizar direitos fundamentais e conter a arbitrariedade, posto que tal é a essência do sistema de freios $\mathrm{e}$ contrapesos: impedir a tirania dos detentores do poder.

Segundo Hely Lopes Meirelles (2010, p. 748 ), todo ato político pode ser submetido ao controle jurisdicional, "pois será sempre necessário que a própria Justiça verifique a natureza do ato e suas consequências perante o direito individual." Para ele, o conteúdo e o motivo dos atos políticos constituem os limites do controle jurisdicional que recai sobre eles, eis que não pode a decisão judicial substituir o ato político: "O que se nega ao Poder Judiciário é, depois de ter verificado a natureza e os fundamentos políticos do ato, adentrar seu conteúdo e valorar seus motivos" (2010, p. 748)

Para alcançar o adequado exercício do controle jurisdicional dos atos políticos, José Joaquim Gomes Canotilho sugere a utilização do princípio da autolimitação judicial, o qual estabelece que "os juízes devem autolimitar-se à decisão de questões jurisdicionais e negar a justiciabilidade das questões políticas" (2003, p. 1308-1309). De acordo com ele, a aplicação princípio da autolimitação judicial não isenta as questões políticas de controle, porquanto estas também devem observar as normas constitucionais, o objetivo de tal princípio é manter a atividade jurisdicional dentro de suas demarcações, sem invadir território estranho a ela.

\section{CONCLUSÃO \\ CONCLUSÃO}

${ }^{7}$ Tradução livre dos autores: "Instalar um tribunal como árbitro supremo do processo do poder - e este é o núcleo da 'judicialização da política' -, transformaria, em última análise, o sistema governamental em um domínio dos juízes ou em uma judiciocracia".
Diante do que foi exposto, pode-se 
concluir que é possível o controle jurisdicional dos atos políticos, porquanto todo ato praticado pelo Estado está vinculado à norma constitucional. Além disto, o Poder Judiciário pode apreciar qualquer ameaça ou violação a direitos individuais ou coletivos, mesmo que advinda do exercício de ato político, por força do princípio da inafastabilidade do controle jurisdicional previsto no Art. $5^{\circ}, \mathrm{XXXV}$ da CRFB/88.

Observa-se, igualmente, que o controle jurisdicional, conforme entendimento pacífico da doutrina, atinge até mesmo os atos políticos. Esta ingerência tem como principal fundamento a necessidade de seu exercício para garantir os direitos fundamentais, mediante a interpretação concretista e do exame de proporcionalidade realizado pelo Poder Judiciário, os quais podem invalidar a eficácia de tais atos, ao declarar-lhes inconstitucionais, a fím de dar prevalência à aplicação das normas de direitos fundamentais de caráter principiológico.

Portanto, o controle jurisdicional dos atos políticos serve como instrumento de concretização dos direitos fundamentais e de correção em conformidade à norma constitucional, porém deve se limitar a alcançar a matéria do ato que possa ser atingida pelo Direito, pelo que deve se abster quanto a assuntos de ordem exclusivamente política, eis que nestas circunstâncias o direito pode se confundir com a política, o que culminaria nos fenômenos da judicialização da política ou da politização da justiça, o que, de uma forma ou de outra, afrontaria o princípio da separação das funções do Estado, sob o risco de a função judiciária extrapolar sua esfera de competência e usurpar aquelas próprias do Governo pertencente às funções executiva ou legislativa.

Então, verifica-se que não pode o controle jurisdicional adentrar o mérito político, a Jurisdição Constitucional deve se limitar àquilo que cabe ao Direito, sem alcançar as questões de realidade exclusivamente política que não podem ser analisadas da perspectiva estritamente jurídica que o Judiciário obrigatoriamente deve lançar sobre o caso concreto. Isto porque a realidade política não envolve somente o Direito, mas também outros fatores de ordem social, econômica e cultural, dado o caráter plurissignificativo das normas constitucionais.

Infere-se, assim, que a discricionariedade do ato político não é absoluta, mas igualmente não é absoluto o seu controle pelo Poder Judiciário, que não pode avaliar o mérito político, nem a motivação do ato. Há, portanto, limites tanto aos atos políticos como ao seu controle, o que certamente corresponde ao sistema de freios e contrapesos com o propósito de alcançar a harmonia entre as funções estatais.

\section{REFERÊNCIAS}

ALEXY, Robert. Teoria dos direitos fundamentais. São Paulo: Malheiros, 2008

APPIO, Eduardo. Controle judicial das políticas públicas no Brasil. $1^{\text {a }}$ ed. Curitiba: Juruá, 2008.

ARISTÓTELES. Política. São Paulo: Martin Claret, 2007.

ÁVILA, Humberto. Conteúdo, limites e intensidade dos controles de razoabilidade, de proporcionalidade e de excessividade das leis. Revista de Direito Administrativo, Rio de Janeiro, 2004.

ÁVILA, Humberto. Teoria dos Princípios: da definição à aplicação dos princípios jurídicos. $4^{\mathrm{a}}$ ed. São Paulo: Malheiros, 2005. 
BARBOSA, Rui. Os actos inconstitucionaes do Congresso e do Executivo ante a Justiça Federal. Rio de Janeiro: Companhia Impressora, 1893.

BARROSO, Luís Roberto. O controle de constitucionalidade no direito brasileiro: exposição sistemática da doutrina e análise crítica da jurisprudência. 6. ed. rev. e atual. São Paulo: Saraiva, 2012

BASTOS, Celso Ribeiro. Comentários à Constituição do Brasil: promulgada em 5 de outubro de 1988 (arts. 5ª 17). São Paulo: Saraiva, 1989.

BOBBIO, Norberto. A era dos direitos. Trad. Carlos Nelson Coutinho. Rio de Janeiro: Elsevier, 2004.

BOBBIO, Norberto. Locke e o direito natural. Trad. Sérgio Bath. Brasília: Ed. UnB, 1997.

BONAVIDES, Paulo. Ciência política. 11. Ed. São Paulo: Malheiros, 2005.

BONAVIDES, Paulo. Curso de direito constitucional. 15ª ed. São Paulo: Malheiros, 2004.

BONAVIDES, Paulo. Do Estado Liberal ao Estado Social. 8ª ed. São Paulo: Malheiros, 2007.

BRASIL. Constituição da República Federativa do Brasil, 1988.

BRASIL. Supremo Tribunal Federal. Mandado de Segurança $\mathrm{n}^{\circ}$ 34070-DF, Relator: Min. Gilmar Mendes, Brasília, DF, 18 de março de 2016. Publicado no DJe-054 de 28 de março de 2016. Disponível em: <http://www.stf.jus.br/arquivo/cms/noticiaNoticiaStf/anexo/ms34070.pdf>. Acesso em: 31 de janeiro de 2017.

CANOTILHO, J. J. Gomes. Direito constitucional e teoria da constituição. $7^{\mathrm{a}}$ ed. Coimbra: Almedina, 2003.

CARVAlHO FILHO, José dos Santos. Manual de Direito Administrativo. 28ª ed.. São Paulo Atlas, 2015.

DI PIETRO, Maria Sylvia Zanella. Direito Administrativo. 27ª ed. São Paulo: Atlas, 2014.

DWORKIN, Ronald. A virtude soberana: a teoria e a prática de igualdade. Trad. Jussara Simões. Revisão técnica e da tradição Cícero Araújo, Luiz Moreira. São Paulo: Martins Fontes, 2005a.

DWORKIN, Ronald. Uma questão de princípio. Trad. Luís Carlos Borges. $2^{\text {a }}$ ed. São Paulo: Martins Fontes, 2005b.

GASPARINI, Diógenes. Direito Administrativo. $8^{\text {a }}$ ed. São Paulo: Saraiva, 2003.

HABERMAS, Jürgen. Direito e democracia: entre facticidade e validade. Vol. I. $2^{\text {a }}$ ed. Rio de Janeiro: Tempo Brasileiro, 2003.

HAMILTON, Alexander; JAY, John; MADISON, James. The Federalist. The Gideon Edition. Edited with na Introduction, Reader's Guide, Constitucional Cross-reference, Index, and Glossary by George W. Carey and James McClellan. Indianapolis: Liberty Fund, 2001. 
HESSE, Konrad. Temas fundamentais do direito constitucional. São Paulo: Saraiva, 2009.

LEITE, Eduardo de Oliveira. A monografia jurídica. 5 ed. São Paulo: Revista dos Tribunais, 2001.

LOEWENSTEIN, Karl. Teoría de la Constitución. Trad. Alfredo Gallego Anabitarte. $2^{\mathrm{a}}$ ed. Barcelona: Ariel, 1976.

MEIRELLES, Hely Lopes. Direito Administrativo Brasileiro. 36a ed. São Paulo: Malheiros, 2010.

MELlO, Celso Antônio Bandeira de. Curso de Direito Administrativo. 27ª ed. São Paulo: Malheiros, 2010.

MONTESQUIEU, Charles de Secondat. Do espírito das leis. São Paulo: Nova Cultural, 2005.

NEVES, Marcelo. Entre Têmis e Leviatã: uma relação difícil: o Estado Democrático de Direito a partir e além de Luhmann e Habermas. $1^{a}$ ed. São Paulo: Martins Fontes, 2006.

OLIVEIRA, Marques. Atos políticos e atos de governo. Revista de informação legislativa, Brasília, Senado Federal, v. 25, n. 99, p. 311-326, jul./set., 1988.

OLIVEIRA, Marques. Controle, esse desconhecido. São Paulo: Revista dos Tribunais, 1983.

PASOLD, Cesar Luiz. Metodologia da pesquisa jurídica: teoria e prática. 11 ed. Florianópolis: Conceito Editorial; Millennium Editora, 2008.

RANELLETTI, Teori degli Atti Amministrativi Speciali. 7. ed. Milano: A. Giuffrè, 1945.

SARLET, Ingo Wolfgang. A eficácia dos direitos fundamentais. $4^{\mathrm{a}}$ ed. Porto Alegre: Livraria do Advogado, 2004.

SILVA, José Afonso da. Curso de Direito Constitucional Positivo. 25 a ed. São Paulo: Malheiros, 2005.

VALLINDER, T; TATE, C. Neal. The Global Expansion of Judicial Power: The Judicialization of Politics. New York: New York University, 1995.

Recebido em: 14/12/2016

Aceito em: 06/02/2017 
